\title{
Perbaikan Iklim Kelas untuk Peningkatan Kualitas Pembelajaran di Perguruan Tinggi
}

\author{
Oleh: \\ Dr. Hadiyanto, M.Ed. \\ Drs. Syahril, Ph.D..
}

\begin{abstract}
Cassroom climate in universities is actually a study that has been done in many universities in other countries, but not much done by researchers at universities in Indonesia. The underlying theories, followed by relevant studies, the development and validation of measuring tools have been widely used and developed to improve the learning process. This article describes the study followed by steps that can be undertaken by researchers and those interested in improving learning through improved classroom climate in universities. Similar research has been conducted at the primary and secondary level in Indonesia, but has not triggered and inspired lecturers, so it is necessary to be undertaken in universities.
\end{abstract}

Katakunci: iklim kelas, perguruan tinggi, pengembangan system, perubahan, hubungan, lingkungan fisik

\section{A. Pendahuluan}

Kajian tentang iklim oleh beberapa ahli dilakukan dengan menggunakan beberapa istilah secara bergantian seperti kata 'climate', atau 'iklim', kemudian kata feel, atmosphere, tone, dan environment (Hadiyanto, 2016). Kata-kata seperti learning environment, group climate dan classroom environment dapat ditemukan di beberapa buku yang terkait dengan iklim kelas. Bloom (1964) menyatakan iklim merupakan kondisi, pengaruh dan rangsangan yang berasal dari luar seperti pengaruh fisik, sosial dan intelektual yang mempengaruhi mahasiswa. Semantara itu, Schmuck dan Schmuck dalam Zedan (2014) mendefinisikan istilah 'iklim kelas' sebagai keseluruhan proses kelompok yang terjadi dalam interaksi antara guru-siswa dan siswa-siswa, termasuk hubungan interpersonal, intonasi emosional dan aspek structural, gaya mengajar dan organisasi kelas, harapan guru siswa dan sikap terhadap mereka, tingkat kontrol guru, masalah disiplin, jenis kelamin dan usia siswa.

Definisi tentang iklim kelas telah banyak dikemukakan para ahli, seperti Newell (1978), Kinney dan Hurst (1980), Moos (1987), Hoy dan Miskell (1982), Hoy dan Forsyth (1986). Dengan berdasar pada beberapa pengertian iklim dan atau iklim kelas di atas, maka dapat dipahami bahwa iklim kelas adalah situasi atau suasana yang muncul akibat hubungan antara dosen dan mahasiswa atau hubungan antar mahasiswa yang menjadi ciri khusus dari kelas dan mempengaruhi proses pembelajaran.

Kajian tentang iklim kelas di perguruan tinggi di Indonesia masih sangat minim dilakukan. Oleh karena itu, mengangkat dan memulai kajian ini secara mendalam menjadi sangat 
relevan dengan pengembangan keilmuan.

\section{B. Dimensi-Dimensi dan Skala Iklim Kelas}

Ada tiga dimensi umum untuk mengukur iklim kelas, yaitu dimensi hubungan (relationship), dimensi pertumbuhan dan perkembangan pribadi (personal growth/development) dan dimensi perubahan dan perbaikan sistem (system maintenance and change) (Moos, 1979). Dimensi hubungan (relationship) mengukur keterlibatan mahasiswa di dalam kelas, saling mendukung dan membantu, dan sejauh mana mahasiswa dapat mengekspresikan kemampuan mereka secara bebas dan terbuka. Dimensi hubungan mencakup aspek afektif dari interaksi antar mahasiswa dan antara mahasiswa dengan dosen. Diantara skala-skala (scales) yang termasuk dalam dimensi ini adalah personalisasi (personalization), dan kekompakan mahasiswa (student cohessiveness).

Dimensi pertumbuhan/perkembangan pribadi, disebut juga dimensi yang berorientasi pada tujuan membicarakan tujuan utama kelas dalam mendukung perkembangan pribadi dan motivasi diri peserta didik. Diantara skala yang terkait dalam dimensi ini adalah orientasi pada tugas (task orientation), kesulitan (difficulty), kemandirian (independence), dan kompetisi (competition).

Dimensi perubahan dan perbaikan sistem (system maintenance and change) membicarakan bagaimana iklim kelas mendukung harapan, memperbaiki kontrol dan merespon perubahan. Diantara skala yang termasuk dalam dimensi ini adalah inovasi (innovation), dan individualisasi (individualization).

Dimensi lingkungan fisik membicarakan sejauh mana kelengkapan sumber, kenyamanan serta keamanan kelas ikut mempengaruhi proses pembelajaran. Skala-skala yang termasuk dalam dimensi ini diantaranya adalah kelengkapan sumber (resource adequacy), keamanan dan keteraturan lingkungan (safe and orderly environment), kenyamanan lingkungan fisik (physical comfort), dan lingkungan fisik (material environment).

Hadiyanto (2016) telah mengidentifikasi 46 skala iklim kelas yang masuk ke dalam empat dimensi tersebut di atas. Skala-skala tersebut diambil dari berbagai alat ukur iklim kelas, mulai dari sekolah dasar, sekolah menengah, sampai dengan perguruan tinggi, yang telah dikembangkan oleh para ahli di berbagai negara.

\section{Iklim Kelas dan Tingkah Laku Mahasiswa}

Untuk melakukan atau tidak melakukan sesuatu, mahasiswa dapat dipengaruhi oleh lingkungan di mana mereka berada atau belajar. Mahasiswa terlatih mengemukakan pendapat dengan baik, karena dosennya memberi contoh, pembelajaran atau memotivasi mahasiswa untuk melakukan itu. Sebaliknya, mahasiswa tidak bisa atau tidak pernah mengemukakan pendapat dengan sopam dan simpatik karena dosennya tidak pernah memberikan kesempatan.

Studi tentang keterkaitan antara iklim kelas dengan tingkah laku mahasiswa sebenarnya telah dimulai oleh Lewin (Hadiyanto, 2004). Dia berpendapat bahwa tingkah laku merupakan akibat dari kaitan antara pribadi orang dengan lingkungan. Pendapat Lewin dapat diformulasikan dalam suatu rumus matematik berikut. 


$$
B=f(P, E)
$$

$\begin{array}{ll}\text { Keterangan } & \mathrm{B}=\text { Behaviour } \\ \mathrm{f} & =\text { function } \\ \mathrm{P} & =\text { Personality } \\ \mathrm{E} & =\text { Environment } .\end{array}$

Maksud formula tersebut adalah, $\mathrm{TL}=\mathrm{f}(\mathrm{K}, \mathrm{L})$, artinya tingkah laku $(\mathrm{TL})$ merupakan fungsi dari kepribadian $(\mathrm{K})$ dan lingkungan (L). Untuk mengetahui dan memprediksi tingkah laku psikologis mahasiswa (B/TL), harus dipahami bermacam-macam peristiwa psikologis seperti tindakan, emosi dan ekspresi seseorang $(\mathrm{P} / \mathrm{K})$ dan lingkungan psikologisnya $(\mathrm{E} / \mathrm{L})$. Dengan demikian pendekatan Lewin ini menekankan pada pentingnya dua hal di atas, yaitu lingkungan dan kepribadian sebagai faktor yang membentuk tingkah laku mahasiswa.

Murray, dalam Fisher (1990) menunjukkan bahwa tingkah laku dipengaruhi oleh kepribadian maupun lingkungan eksternal. Dia mengajukan suatu model kebutuhan dan tekanan (press) yang dapat dianalogkan seperti pribadi dan lingkungan. Kebutuhan pribadi mengacu pada motivasi individu untuk mencapai suatu tujuan tertentu, sedangkan lingkungan 'press' merupakan situasi eksternal yang memicu atau menyebabkan kekacauan dalam mengungkapkan kebutuhan pribadi.

\section{Iklim Kelas dan Prestasi Belajar}

Meskipun prestasi belajar mahasiswa dipengaruhi oleh banyak aspek seperti gaya belajar, fasilitas, dan factor lainnya, pengaruh iklim kelas masih sangat penting. Ketika para mahasiswa belajar di lingkungan kelas, baik itu lingkungan fisik maupun non-fisik dapat mendukung atau bahkan mengganggu mereka. Oleh karena itu, Hyman (1980) mengatakan bahwa iklim yang kondusif antara lain dapat mendukung: (1) interaksi yang bermanfaat di antara mahasiswa, (2) memperjelas pengalaman- pengalaman dosen dan mahasiswa, (3) menumbuhkan semangat yang memungkinkan kegiatan-kegiatan di kelas berlangsung dengan baik, dan (4) mendukung saling pengertian antara dosen dan mahasiswa. Moos (1979) juga mengatakan bahwa iklim sosial mempunyai pengaruh yang penting terhadap kepuasan mahasiswa dalam belajar. Kedua pendapat itu sangat beralasan karena hal-hal tersebut pada akhirnya akan mempengaruhi prestasi belajar mahasiswa.

Fraser (1986) mendokumentasikan lebih dari 45 penelitian yang membuktikan adanya hubungan yang positif antara iklim kelas dengan prestasi belajar siswa dan mahasiswa. Penelitian-penelitian itu menggunakan berbagai macam alat ukur iklim kelas yang telah dikembangkan di negara-negara maju seperti USA, Canada, Australia, India, Jamaica, Brazil dan Thailand.

Kesimpulan dari beberapa studi tersebut menunjukkan bahwa prestasi belajar mahasiswa juga ditentukan oleh kualitas iklim kelas tempat mereka belajar. Dengan demikian, prestasi belajar mahasiswa dapat ditingkatkan dengan menciptakan iklim kelas yang kondusif dan lebih baik.

\section{E. Studi tentang Iklim Kelas di Perguruan Tinggi dengan Variabel Lainnya}

Penelitian tentang iklim kelas di perguruan tinggi telah dimulai Treagust dan Fraser pada tahun 1986. Penelitian-penelitian tentang iklim kelas tersebut ada yang bersifat deskriptif, 
korelasional maupun pengembangan (Treagus dan Fraser, 1986). Studi ini dilaksanakan untuk pengembangan, validasi, dan penggunaan instrumen penelitian, College and University Classroom Environment Inventory (CUCEI), yang dirancang untuk menilai iklim kelas di perguruan tinggi. Instrumen CUCEI digunakan untuk mengetahui persepsi mahasiswa atau dosen dosen lebih memilih iklim kelas yang lebih baik daripada yang sebenarnya ada. Para dosen memandang bahwa iklim kelas yang mereka ciptakan lebih positif daripada yang dipersepsi tentang tujuh dimensi psikososial, yaitu: personalisasi (personalization), keterlibatan (involvement), kekompakan siswa (student cohesiveness), kepuasan (satisfaction), orientasi pada tugas (task orientation), inovasi (innovation), dan individualisasi (individualization). CUCEI actual form dan preferred form didistribusikan kepada 372 mahasiswa di 34 kelas dan 20 dosen. Penelitian dilakukan untuk mengetahui reliabilitas, konsistensi internal, dan validitas diskriminan alat ukur.

Penerapan penelitian dengan menggunakan CUCEI ini menyarankan bahwa iklim kelas itu mempengaruhi hasil belajar mahasiswa. Penelitian yang lain menunjukkan bahwa baik mahasiswa maupun oleh mahasiswa. Treagust dan Fraser (1986) mengharapkan CUCEI ini dapat diaplikasikan di masa yang akan datang untuk tujuan penelitian dan dalam rangka meningkatkan proses pembelajaran di perguruan tinggi.

\section{F. Tahap-tahap Perbaikan Iklim Kelas di Perguruan Tinggi}

Fraser, Seddon dan Eagleson (1982), Fraser (1986) mengajukan lima langkah untuk melakukan perbaikan iklim kelas dengan membandingkan iklim kelas yang dialami (actual climate) dan yang diinginkan mahasiswa (preferred climate). Kelima langkah itu adalah: penilaian awal (assessment), umpan balik (feedback), refleksi dan diskusi (reflection and discussion), campur tangan perbaikan (intervention) dan penilaian ulang (reassessment).

1. Penilaian Awal (Assessment)

Langkah ini dilakukan dengan membagikan dua macam angket, alat ukur iklim kelas yang dialami (actual form) dan alat ukur iklim kelas yang diinginkan mahasiswa (preferred form). Alat ukur actual form dibagikan pertama, kemudian dilanjutkan dengan alat ukur preferred form beberapa waktu berikutnya. Dapat juga dilaksanakan dengan membagikan angket actual form kepada separuh mahasiswa dan angket preferred form kepada sebagian mahasiswa yang lain.

2. Umpan Balik (Feedback)

Setelah data dari langkah pertama diolah, dosen diberi tahu hasil analisis actual maupun preferred form. Pada tahap ini dosen dapat mengetahui apakah ada perbedaan yang berarti antara iklim kelas yang dialami dan iklim kelas yang diinginkan mahasiswa. Apabila ada perbedaan, dan mungkin perbedaan pada skala tertentu sangat tajam, dosen dapat melakukan perubahan untuk mengurangi kesenjangan skala tertentu itu.

3. Refleksi dan Diskusi (Reflection and Discussion)

Pada tahap ketiga ini dosen melakukan diskusi secara formal maupun informal dengan dosen-dosen lain tentang profil mengajarnya, serta membicarakan perlunya perbaikan iklim kelasnya. Dosen bebas memilih skala-skala tertentu yang perlu diprioritaskan untuk diperbaiki sesuai dengan kebutuhan mahasiswa saat itu. Apabila pada skala inovasi terdapat perbedaan yang mencolok antara keadaan yang dialami dengan yang 
diinginkan oleh mahasiswa, dosen dapat mengurangi kesenjangan ini dengan meningkatkan inovasi kelas.

\section{Campurtangan Perbaikan (Intervention)}

Apabila seorang dosen memilih untuk meningkatkan inovasi kelas, yang bersangkutan melakukan upaya itu misalnya dengan lebih sering memberikan informasi tentang temuan-temuan baru di bidang teknologi dan informasi dan mengimplementasikannya di kelas. Langkah ini dapat dilaksanakan dua sampai tiga bulan, atau tergantung pada kebutuhan. Semakin banyak skala yang akan diubah dan ditingkatkan, semakin lama waktu yang dibutuhkan dosen untuk melakukan perbaikan itu.

5. Penilaian Ulang (Reassessment).

Apabila dosen menganggap bahwa langkah intervensinya telah cukup, selanjutnya dosen melakukan penilaian ulang (reassessment) dengan membagikan kembali alat ukur iklim kelas actual form. Hasil penilaian ulang ini kemudian dibandingkan dengan hasil penilaian yang pertama. Apabila terdapat peniingktan dan perbedaan yang berarti antara iklim kelas yang dialami mahasiswa sebelum dengan iklim kelas sesudah intervensi perbaikan, maka langkah perbaikan dapat dikatakan berhasil. Namun sebaliknya, apabila belum ada perbedaan yang berarti, dosen dapat mengulangi langkah ini sampai yang bersangkutan yakin ada peningkatan pada skala seperti yang dia kehendaki.

\section{G. Penelitian tentang Iklim Kelas dan Iklim Sekolah di Indonesia}

Meskipun penelitian tentang iklim kelas dan iklim sekolah di Indonesia belum banyak dilakukan, Hadiyanto beserta kolega lainnya telah menunjukkan bahwa studi tentang iklim kelas dan iklim sekolah perlu dilakukan untuk memperkaya khasanah keilmuan dan menjadi kajian yang dapat digunakan untuk membantu melakukan perbaikan proses pembelajaran dan penyelenggaraan pendidikan. Berikut adalah penelitian-penelitian yang telah dilaksanakan.

1. Pengembangan dan Validasi Alat Ukur Iklim Kelas Sekolah Dasar (Hadiyanto dan Mukti, 1997)

Penelitian ini dilakukan oleh Hadiyanto dan Basori Mukti pada tahun 1997 untuk memvalidasi alat ukur iklim kelas sekolah dasar. Responden yang memvalidasi alat ukur ini sebanyak 1126 siswa kelas V dan VI sekolah dasar di Sumatera Barat (561 siswa merespon alat ukur iklim kelas actual form, dan 565 merespon alat ukur iklim kelas preferred form. Hasil penelitian ini menunjukkan bahwa alat ukur iklim kelas yang dikembangkan dan divalidasi lebih baik dibandingkan dengan alat ukur yang telah divalidasi sebelumnya.

2. Perbaikan Iklim Kelas yang Kurang Demokratis pada Sekolah Dasar No. 19 Padang Utara (Muhammad, Hadiyanto, dan Nurli, 1998).

Penelitian ini dilakukan oleh Arni Muhammad, Hadiyanto, dan Nurli pada tahun 1998 pada kelas V Sekolah Dasar No. 19 Padang Utara. Hasil penelitian ini menunjukkan terdapat perbedaan yang signifikan antara demokrasi kelas pada saat sebelum dan sesudah intervensi dilakukan. 
3. Pengembangan dan Pemvalidasian Alat Ukur Iklim Sekolah (Hadiyanto dan Syahril, 2000)

Penelitian ini dilakukan oleh Hadiyanto dan Syahril pada tahun 2000 untuk memvalidasi alat ukur iklim sekolah dasar. Responden yang memvalidasi alat ukur ini sebanyak 821 guru sekolah dasar di Kota Padang, Padang Panjang, Bukittinggi, dan Payakumbuh Sumatera Barat (418 guru merespon alat ukur iklim sekolah actual form, dan 403 merespon alat ukur iklim sekolah preferred form. Hasil penelitian ini menunjukkan bahwa alat ukur yang divalidasi dapat digunakan untuk studi lebih lanjut.

4. Peningkatan Proses Pembelajaran melalui Perbaikan Iklim Kelas di SD YWKA II Rawamangun, Jakarta (Sutjipto dan Hadiyanto, 2002)

Penelitian ini merupakan penelitian tindakan kelas yang dilaksanakan oleh guru Mada, guru kelas V SD YWKA II Rawamangun, Jakarta bersama Sutjipto dan Hadiyanto pada tahun 2002. Hasil penelitian ini menunjukkan bahwa pada skala kepuasan (satisfaction) terdapat perbedaan yang berarti antara iklim kelas sebelum dan sesudah tindakan perbaikan. Meskipun demikian, perubahan perbaikan tersebut belum optimal seperti yang diharapkan oleh peserta didik (preferred climate).

5. Upaya Kepala Sekolah dalam Menciptakan Iklim Sekolah Dasar di Jakarta (Sutjipto dan Hadiyanto, 2003)

Penelitian ini merupakan penelitian komparatif yang dilaksanakan di lima Sekolah Dasar Angkasa Halim Perdana Kusuma, Jakarta bersama Sutjipto dan Hadiyanto pada tahun 2003. Hasil penelitian ini menunjukkan bahwa pada sekolah yang iklimnya kurang kondusif, prestasi dan kondiri umum manajemennya tidak lebih baik dibandingkan dengan sekolah yang iklimnya kondusif. Perbedaan dukungan murid dapat ditunjukkan oleh kekompakan dan pola kerjasama serta komunikasi antara para siswa, siswa dengan guru dan siswa dengan kepala sekolah; Perbedaan afiliasi, minat profesional, dan kebebasan staf diduga kuat sangat berkait dengan kemampuan manajerial kepala sekolah dan sangat berkait dengan kondusif atau tidak kondusifnya iklim sekolah di mata guru.

6. Perbaikan Iklim Kelas untuk Peningkatan Kualitas Pembelajaran di Sekolah Dasar Kecamatan Koto Tangah Kota Padang (Hadiyanto, Anisah, AlKadri, Santoso, 2017)

Studi ini merupakan langkah kegiatan dari Pengabdian Masyarakat yang dilaksanakan oleh Hadiyanto dan team dari Jurusan Administrasi Pendidikan FIP Universitas Negeri Padang pada sepuluh (10) sekolah dasar di Kecamatan Koto Tangah Kota Padang. Hasil studi ini menunjukkan bahwa terdapat perbedaan yang cukup mencoolok antara skala kepuasan (satiscation) dan keakraban (cohesiveness) yang dialami peserta didik (actual climate) dibandingkan dengan yang diinginkan peserta didik (preferred climate). Dari hasil ini maka diperlukan langkah-langkah treatmen untuk membuat agar kedua skala tersebut menjadi lebih kondusif untuk mendukung pembelajaran yang lebih optimal.

Mengingat penelitian-penelitian tersebut di atas baru dilaksanakan di tingkat sekolah dasar dan sekolah menengah, maka diperlukan juga pengembangan penelitian terkait dengan iklim kelas di perguruan tinggi. 


\section{Referensi}

Arter, J.A. 1989. Assessing School and Classroom Climate. Portland, Oregon: Test Centre of the Northwest Regional Educational Laboratory.

Bloom, B. S., 1964, Stability and Change in Human Characteristics, New York: Wiley.

Fisher, D.L., 1990, The Assessment and Change of Classroom and School Environment. Launceston: Tasmanian State Institute of Technology.

Fraser, B. J., 1986, Classroom Environment, London: Croom Helm.

Fraser, Seddon dan Eagleson

Hadiyanto. 2004. Mencari Sosok Desentralisasi Manajemen Pendidikan di Indonesia. Jakarta; Rineka Cipta.

Hadiyanto. 2016. Teori dan Pengembangan Iklim Kelas dan Iklim Sekolah. Jakarta: Prenada.

Hadiyanto, Anisah, AlKadri, H., Santoso, Y. 2017. Perbaikan Iklim Kelas untuk Peningkatan Kualitas Pembelajaran di Sekolah Dasar Kecamatan Koto Tangah Kota Padang. Padang: Universitas Negeri Padang.

Hadiyanto dan Kumaidi. 1998. Pengembangan dan Pemvalidasian Alat Ukur Iklim Kelas di Sekolah Lanjutan Tingkat Pertama, IKIP Padang, Padang.

Hadiyanto dan Mukti, B. 1997. Pengembangan dan Validasian Alat Ukur Iklim Kelas Sekolah Dasar, IKIP Padang, Padang.

Hadiyanto dan Syahril. 2000. Pengembangan dan Pemvalidasian Alat Ukur Iklim Sekolah, IKIP Padang, Padang.

Hoy, W. K. and Miskell, C. G., 1982, Educational Administration: Theory, Research and Practice, New York: Random House.

Hyman, R. T., 1980, School Administrator's Handbook of Teacher Supervision and Evaluation Methods. New Jersey: Prentice-Hall, Englewood Cliffs.

Muhammad, Hadiyanto, dan Nurli.1998. Peningkatan Iklim Kelas yang Kurang Demokratis di Sekolah Dasar No. 19 Kecamatan Padang Utara, IKIP Padang, Padang

Moos, Rudolf H. 1979, Evaluating Educational Environments, Washington: Jossey-Bass Publishers.

Sutjipto dan Hadiyanto. 2002. Supervisi Berbasis Iklim Kelas, Penelitian Tindakan di SD YWKA II Rawamangun Jakarta', Forum Pendidikan. Nomor 04, Tahun 27, Desember 2002.

Sutjipto dan Hadiyanto. 2003. Upaya Kepala Sekolah dalam Menciptakan Iklim Sekolah Dasar di Jakarta. Jakarta: Universitas Negeri Jakarta.

Thapa, Amrit, dkk. 2012. School Climate Research Summary. New York: National School Climate Center. 
Treagust, D. F.,. Fraser, B. J., 1986. Validation and Application of the College and University Classroom Environment Inventory (CUCEI).Paper, presented at the Annual Meeting of the American Educational Research Association (67th, SanFrancisco, CA, April 16-20, 1986).

Zedan, Raed. 2010. 'New Dimensions in the Classroom Climate'. Learning Environ Res. 2010. 13: 75-88. 